\title{
Tracing Cultural Morphing and Diasporic Identical Apprehensions: Post-Partitioned (1947) Contextual Ideologies in Liquid Modern Era
}

\author{
Hassan Bin Zubair*, Dr. Nighat Ahmed**
}

\begin{abstract}
This research explores the diasporic experiences of South Asian immigrants and cultural ambivalence in Kiran Desai's The Inheritance of Loss (2006). It highlights the conditions when East Pakistan had to adjust to an altogether new environment separated from their original culture after the Partition of this subcontinent in the year 1947. It reveals that the same historical, ideological, and thematic properties have been coming through generations and diasporic writers select these themes as their major subject of discussion. This research explores the varied nuances of family relationships in the writings of recent diaspora writers like Desai. The surge of globalization has washed away solitary identities. Theories presented by Homi K. Bhabha and Stuart Hall help this study in finding the answers of the proposed research question. This research provides a chance to understand the impact of Post-Partitioned (1947) ideologies behind the theme selection in the writings of diasporic Anglophone writers.
\end{abstract}

Keywords: Post-Partition, History, Diaspora, Culture, Immigrants, Hybridity, Identity.

This Article can be cited as:

Zubair H., Ahmed N., (2020). Tracing Cultural Morphing and Diasporic Identical Apprehensions: Post-Partitioned (1947) Contextual Ideologies in Liquid Modern Era, Journal of Arts and Social Sciences. VII (2), 150-161.

\footnotetext{
* Correspondence concerning this article should be addressed to Hassan Bin Zubair, PhD Scholar (English Literature), National University of Modern Languages, Islamabad hbz77@yahoo.com.

** Dr. Nighat Ahmed, Assistant Professor of English, Department of English, National University of Modern Languages, Islamabad, Pakistan, drnighatahmad@gmail.com.
} 


\section{Introduction}

This research article is based on my unpublished doctoral thesis of English Literature, in which I have tried to explore the bicultural ambivalence and issues related to Identity, economy, culture, religion, and ideology in Indian diasporic Anglophone fiction. This research explores the diasporic experiences of South Asian immigrants and cultural ambivalence in Kiran Desai's The Inheritance of Loss (2006). It provides a chance to understand the impact of Post-Partitioned (1947) ideologies behind the theme selection of diasporic Anglophone writers. Multi-cultural societies are the result of the extensive movement of people that has been taking place in the second half of the last century. Kiran Desai writes about characters caught between the two completely separate worlds of the host and home countries. The latter half of the twentieth century saw the gradual decolonization of developing countries which resulted in diasporic pieces of literature that have successfully secured their place alongside other European literature. It has been assumed and generally accepted that multi-culturalism is responsible for this new genre of Indian diasporic writing, which is again an offshoot of postmodernism that advocates and promotes multi-ethnic societies. The surge of globalization has washed away solitary identities. Zygmunt Bauman calls this age of increased mobility as the "liquid modern era" (Bauman, 1996). The existential fragmentation dismantling the absolute notions of identity that proclaim man's existence as unitary has been gradual but steady. Living in voluntary exile and finding difficulties in identifying with the alien society lead to a person who is 'unhomed'. The profound uncertainties that an immigrant faces bring forth an 'inbetween' situation that again gives birth to hybrid identities.

There are two kinds of Diasporas, the diaspora of indentured labourers who went to work in the nineteenth century in the plantations and the more recent migration of professionals in the skilled sectors. Vijay Mishra classifies the two kinds as "old or exclusive" and the "new or border" Indian diasporas (Mishra, 1996). The old diaspora is exclusive because the indentured labourers were more or less selfcontained and created 'little Indias' in the colonies. They resisted all attempts to mix with the host nation. Mishra believes that V.S. Naipaul is the founding writer of the old Indian diaspora. Mobility characterizes the newer kind or the 'border' diaspora. Salman Rushdie, Jhumpa Lahiri, Rohinton Mistry, Kiran Desai and others write about the new diaspora. This new 'border' diaspora is not as exclusive as the 'old' kind. Thanks to technological advancements in communication, new diasporic communities can maintain contact with their home countries easily. Robin Cohen, on the other hand, opines that "there are five different types of diasporic communities, corresponding to those of victims, labourers, traders, imperialists, and cultural suppression" (qtd. In Anthias, 1998). However, such communities can take dual or multiple forms or change their characteristics over a while. Rushdie observes that "America, a nation of immigrants, has created great literature out of the phenomenon of cultural transplantation, out of examining the ways in which people cope with a new world" (qtd. in Gangopadhyay, 2010). Such communities carry traces of hyphenated subjectivities. They are visible presences; in the words of the Chicano novelist John Rechy, "we are seen, therefore we are" (qtd. Castillo, 1995).

\section{Indian Diaspora}

During the period of the 9th and 10th centuries CE, Indian kings sent military and commercial expeditions to far off places. The primary aim was to attain economic prowess in the region. The expeditions established contact between the homeland and foreign nations. Indians linked with trade and commerce settled in Malaya and Burma. There were also movements of Indians to West Africa. The Indian diaspora attained momentum during the British imperialist rule when Indian labourers were sent to Canada, Africa, West Indies, and islands like Mauritius and Fiji. Even today we find many Indians living in the aforementioned places for generations. The first batch of indentured labourers was sent to Mauritius in the 1830s and this system continued till 1917 (Mishra, 1996). It is estimated that around a million people were transported from India to Mauritius, South Africa, Trinidad, Guyana, Surinam, and Fiji to work in the sugarcane plantations. A small number of Indians also migrated to Sri Lanka to work in the tea plantations. 
But after the Second World War, the movement of Indians attained a whole new meaning and became an important phenomenon to be reckoned with.

\section{Research Objectives}

- To highlight the features of Post-Partitioned ideology in diasporic subjects and how it works in the writing of diasporic Anglophone writers.

- To present the cultural morphing in the liquid modern era.

- To highlight the societal gaps based on culture, religion, and economy.

\section{Research Questions}

Q.1: How have historical ideologies worked in the theme selection of Post-Partitioned (1947) subjects in the writings of South Asian diasporic Anglophone writers?

Q.2: How has Kiran Desai projected the diasporic cultural ambivalence in the novel The Inheritance of Loss?

Q.3: How have been the issues of family, religion, and culture highlighted in Indian diasporic Anglophone fiction?

Q.4: While living in the liminal space, how have the problems related to the first and second generations been brought to light in the selected text?

\section{Theoretical framework and Research Methodology}

This research is qualitative in nature and textual analysis is used as a central method of analysis. Multiple theories have been used for the textual analysis of the selected text for this study. Theories presented by Homi K. Bhabha and Stuart Hall helps the researcher in finding the answers to the research questions proposed for this study. Stuart Hall believes that identity is a "production, which is never complete, always in process" (Hall, 1990). It transforms and is never fixed to an "essentialised past" (Hall, 1990). Agreeing with Hall, Mishra believes that the new Indian diaspora of border is a site for "rearticulation of an intercultural formation" (Mishra, 1996) that is heterogeneous in character and advocates the synthesis of different cultural trajectories. Drawing on Rushdie, Mishra adds that "the marginality of the Indian diaspora becomes a highly interrogative space from which one is more willing to explore contaminated, impure relationships, thereby, creating new and vibrant forms of transculturation" (Mishra, 1996). Mary Louise Pratt explains the term transculturation as a "a phenomenon of the contact zone" (Ashcroft, Griffiths and Tiffin, 2009). Pratt further defines that "contact zones are social spaces where disparate cultures meet often in highly asymmetrical relations of dominance and subordination" (Ashcroft, Griffiths and Tiffin, 2009).

\section{Textual Analysis}

Inheritance of Loss does not record inter-generational differences in the context of diaspora. However, it does show different cultural trajectories running through the narrative. The retired judge adores the British imperialist culture so much that he readily abandons his native Gujarati rituals and customs that eventually leads to marital discord in his life as well as isolation from the other members of his family. His grand-daughter having studied in an English-medium convent school is more at ease with English customs and manners than with Hindi. Biju, the son of the cook, goes to New York with the hope that he will earn enough money and be materially successful but ultimately returns to India empty-handed. Biju does not show in himself any trace of the mainstream American culture, because he resists being a part of it. Indulging in nostalgia, Biju remembers his father in Kalimpong and its familiar surroundings. The characters in The Inheritance of Loss experience losses during and after their process of migration. They inherit elements of multiple cultures that have a direct bearing on their family dynamics. 
Therefore, transculturation and transnationalism are important in this research as Desai uses these concepts in her respective narrative, albeit differently. The research takes into account how different families negotiate diverse geographical, emotional, and cultural terrains and eventually end up being transnationals and carriers of multiple cultures. Ultimately, the novels end by showing a re-confirmation of family relations in the context of migrancy. While discussing the characters' coming in contact with a different culture, I use Bhabha's use of the term 'mimicry' in this research. The judge migrates to England as a young student because he had perceived the British system of education as the best in the world that will empower him socially when he comes back to India. However, the judge faces racial discrimination to the extent that he indulges in extreme bouts of self-hatred. When he finally returns to India, he begins to follow British ways and customs and thinks himself to be socially superior to his other family members. This leads to discord in his family relations. Bhabha believes that "mimicry ... 'appropriates' the Other as it visualises power" (Bhabha, 1994). Jemubhai assumes that by mimicking British ways and customs he can subvert years of subjugation that he and his family had been subjected to in pre-independence India and the process, assume social prestige and authority. Bhabha's definition of mimicry explains the psyche of the anglophile judge and thus it is an important term to be analyzed in the paper.

The Inheritance of Loss has characters from different generations, the novel does not reflect a generational difference in the context of diaspora. However, the novel eschews the notion that culture is a fixed site of meaning. Robin E. Field analyses the second-generation's dual alienation from the host nation's cultural territory. In this context, Field quotes Min Zhou: "'Many second-generation Asian-Americans, who are considered assimilated, are still subjected to a pernicious system of racial stratification .... The truth is, no matter how American you think you are or try to be, if you have almond-shaped eyes, straight black hair, and a yellow complexion, you are a foreigner by default"' (Field, 2004). The second-generation is thus stuck in a "liminal space of cultural borderlands" (Field, 2004). In The Inheritance of Loss, I observe that most of the critics explore subjects like the judge's anglophile nature and Biju's isolation in the US because of his illegal status. Commenting on the judge's psyche, David Wallace Spielman explores that "the judge's humble peasant background and how the judge negotiates his newfound position as an ICS officer after he returns from England" (Spielman, 2010). Spielman does not explore in detail the effects of the judge's anglophilic nature on his relationships with his wife and his family members. Focusing on the character of Biju, Spielman concentrates on Biju's miserable existence and his determination to make a living in the US despite his illegal status. Spielman draws a parallel between Biju and the judge and comments that both the characters are motivated to go to the west because of socio-economic compulsions. The critic believes that both the characters attempt to create an exaggerated picture of social and financial success abroad because neither of them wants to project himself as "being a postcolonial person forced into contact with cultures in conflict" (Spielman, 2010). Rather they try to frame an appearance of success through their communication with the other family members. Spielman's observations throw light on the contexts of the judge and Biju's migration. However, the critic does not explore the effect of the characters' migration on their family relations. Margaret Scanlan analyses The Inheritance of Loss as a political novel and analyses the narrative in the context of the aftermath of 9/11. Scanlan believes that "the paranoia that is there about immigrant characters like Biju and Saeed is obvious given the fact that the novel is written after the Twin Tower attacks" (Scanlan, 2010). The critic hints at the elements of cynicism the novel contains. Scanlan continues that political disturbance directly affects the characters in some way or the other. Although Scanlan does not focus on the effects of the Gorkhaland movement on family relationships, the critic does explore the significance of Biju's return from the US and his subsequent robbing by the insurgents. Scanlan comments that Biju's return to India can be regarded as "the least heroic homecoming" (Scanlan, 2010) in the sense that he cannot be identified as a person who has just returned after a successful life in the US. I carry forward this observation of Scanlan and explore how Biju's return from the US and his subsequent reunion with his father reaffirms the bond of unadulterated love between father and son. 
Yu-yen Liu explores the elements of multiculturalism in The Inheritance of Loss (Liu, 2009). Liu explores the formation of racial and cultural identities that straddle "multiple national sites" (Liu, 2009). Liu believes that the novel's two world approach suggests that Desai's inclination to "re-border cultural reality" (Liu, 2009) is necessary to explore the demands of a transnational world. In subsequent discussions, Liu explores transnationalism as reflected in Desai's novel and gives a detailed discussion of how Desai's characters are cultural hybrids, identified by their multiple cultural affiliations. However, Liu does not explore the effects of such multicultural affiliations on the inter-personal relations of the characters within the space of the family. Critics like Sanghita Sen and Beena Agarwal have explored the psychological terrain of characters like the judge and Biju who migrate to other countries to assume a state of power. Sanghita Sen observes that for the young England-returned Jemubhai, "participation in colonial administration is viewed as a tool of empowerment" (Sen, 2009). The principal characters of the novel come from the position of the 'other'. Jemubhai comes from a poor peasant family that does not have an empowered social status in colonial India. Biju comes from a poor family; his father works as a cook for a paltry sum of money. For these characters, migration provides a source of escape as well as an opportunity for empowerment. Speaking in the same vein, Beena Agarwal focuses her analysis on the cook who regards the US as "the best country in the world" (Agarwal, 2009). For a poor man like the cook, sending his only son to the US makes him feel extremely happy and motivates him to think that his son must be very successful working there. However, the reality is completely different which he is unaware of. Biju realizes that his status as an illegal immigrant in the US makes him vulnerable and he is continuously exposed to a situation where even turning back is impossible because of his lack of papers. At the same time, the cook puts up a false appearance that everything is all right in Kalimpong, whereas in reality, the hill town is on the boil because of the Gorkhaland insurgency. These apparent attempts to hide the reality from one another show how both the characters care for each other. At the end of the narrative, Biju's reunion with his father affirms the bond between them and establishes the strength of filial love without any material expectations or desires.

Duara explores the reasons behind the judge's isolation, his anglophilic nature, and also the other characters' experiences of loss that occur in some way or other at some point in the narrative. Duara's analysis also takes into focus Biju's isolation in the US and his desperate attempts to get a Green Card from the American authorities. The critic believes that the seemingly disparate characters share a similar "historical legacy as well as a common experience of impotence and humiliation" (Duara, 2009). The characters in The Inheritance of Loss are subjected repeatedly to the economic and cultural power of the West at different points in history. This subjugation directly affects their family relationships as each one of them tries to put on a mask of success to prove their superiority over others. This study explores how family relationships are altered and affected throughout the narrative because of travel by characters like the judge and Biju. The judge returns to find himself surrounded by relatives who are not western-educated as he is, whereas Biju returns "sans dollars, sans leather jacket and sans any sign of American possessions whatsoever" (Rehman, 2009). I explore Rehman's arguments further and examine how inter-personal dynamics within the unit of the family directly related to travel by the characters. Speaking about women in the context of diaspora, Gayatri Spivak comments that women are the worst victims in the context of migration. She continues that women are "super dominated, super-exploited" (Spivak, 1996) when they have to migrate to a completely new country. They can never reap the benefits of migration nor can they adjust to the new surroundings. They are "never the full subjects of and agents in civil society: in other words, first-class citizens of a state" (Spivak, 1996). Spivak believes that a migrant woman's entire energy is spent on her attempts at successful transplantation or insertion into the new state (Spivak, 1996). Thus the migrant woman is relegated to a state of non-entity where she finds the little scope of interacting with other people and, thereby, becomes the victim of migrant activism.

Desai is successful in illuminating the pain of exile of the characters who are caught in the vortex of globalization. The novel spans generations, cultures, religions, and races. She successfully illustrates how individual characters living in different parts of the planet often intersect in surprising ways. A father's 
love for his son, the son's ambition to succeed, the bitterness of a lonely man living out his last days in a small town in the north-eastern Himalayas, two sisters' yearning for the past are all presented by Desai as dislocated frail human beings in search of love and happiness. Sunita Sinha describes The Inheritance of Loss as

"A perspective, an inside look into post-independence India, with its roots dug in colonialism, its branches embracing Americanism, but it leaves brown and dusty with the age-old prejudices that govern people's minds; an India where a class of people still speak only English and squirm at the mention of their mother tongues; where a mother is proud because her daughter has chosen to marry an Englishman; where a foreigner is treated suspiciously in spite of his honest efforts to lay foundations of indigenous industries; where thousands of Indians enter America as illegal immigrants in the eyes of their families, they are the heroes, but in reality, they sleep with mice on the kitchen floors of restaurants or in squalid suburbs of big cities" (Sinha, 2009).

Set against the backdrop of Kalimpong, Manhattan, and the Gorkhaland movement in India, The Inheritance of Loss explores anglophilia and issues of colonialism, racism, immigration, young love, regret, and hope. Kiran Desai uses familiar modernist/postmodern devices, such as disjunctive chronology to revise the West's vision of itself as a haven for the oppressed. She speaks about the oppression of people when they migrate to the West. Given that much of the book was written after the 9/11 attacks, there could have been hints of paranoia about immigrants as sources of contagion and explosions. Desai explores the pain of the immigrant in a world where "one side travels to be a servant, and the other side travels to be treated like a king" (Sinha, 2009). Her scope is broad, looking at the consequences of large cultural and political forces for both people and individuals.

Biju resists all attempts to be a part of the mainstream American culture while Jemubhai leaves no stone unturned in his efforts to be a part of the British culture, resulting in his alienation from his countrymen and relatives. Yu-yen Liu defines transnationalism as the "historically specific processes of globalisation" that began at the end of the twentieth century. Kandice Chuh defines transnationalism as "a socio-political collectivity produced in diversely local and global articulations within an ever-changing matrix of nationalisms and circumscribed by the flow of capital within and across national boundaries" (Chuh, 1996). This concept of transnational transforms the idea of national boundaries caused by the shifts of global and local, political, economic changes and most importantly, by the gradual obliteration of specific cultural terrains, resulting in an interdisciplinary perspective that is reflected in the novel. Khachig Tololyan seconds Kandice Chuh and comments that

"Diaspora is undergoing an accelerating transition from exilic nationalism to diasporic transnationalism ... this transition is challenging the agendas, discourses, and resources of existing institutions, causing changes and occasionally leading to the creation of new organisations." (Tololyan, 2000)

Andrew Smith quotes Bhabha that there is " "no necessary or eternal belongingness"” (Smith, 2004, p.248). "It is the ... cutting edge of translation and negotiation, the in-between space that carries the burden of the meaning of culture" (Smith, 2004). This continuous negotiation through a different cultural process shapes the characters in different ways as each one of them comes from varying points of history and looks at the culture of the host nation in different ways. Jemubhai Patel goes to Cambridge to study law in 1939. On a departing day, for the very first time, "he felt a piercing fear, not for his future, but for his past, for the foolish faith with which he had lived in Piphit" (TIOL 41). He harbored an idealised love of England where "he'd expected only grandness." But this expectation of his is soon shattered when he sees "tiny gray houses in gray streets, stuck together" (TIOL 38). He "hadn't realised that here, too, people could be poor and live 
unaesthetic lives" (TIOL 38). He sees the sight of small gray houses with a sense of amazement for the glorious picture of England that he had carried in his heart now seems colourless. England, for him, had been a land of dreams that is shattered when he reaches Cambridge. Jemubhai's lonely life is spent locked inside his room. Without any company, he gradually withdraws into himself. Jemubhai immerses himself in hard work to forget his loneliness that was slowly gripping him in the alien country.

"He worked twelve hours at a stretch, late into the night, and in this withdrawing, he failed to make a courageous gesture outward at a crucial moment and found, instead, that his pusillanimity and his loneliness had found fertile soil. He retreated into a solitude that grew in weight day by day. The solitude became a habit, the habit became the man, and it crushed him into a shadow." (TIOL 45)

He feels the 'secondariness' of his existence in England. He is mocked for his skin colour. The young Jemubhai gradually becomes a stranger to himself and feels lost and humiliated. His mind begins to warp and he finds his own skin odd coloured, his accent peculiar. He forgets how to laugh, and can barely manage to smile. Even when he does, he holds his hand over his mouth lest anyone sees his teeth. Jemubhai is wrongly accused of smelling like curry by some young British girls, he takes to regular washing and covers himself completely. The impact of being discriminated against affects his psyche so much that Jemubhai becomes obsessive for faded days lest sunlight reveals his coloured skin to the English people. The residual traces and memories of the subordination of Indians in the hands of the British affect his psyche deeply. Desai's detailing of the judge's obsession with his physical appearance demonstrates how the young Jemubhai is affected when he is discriminated against by the British based on his skin colour:

"He began to wash obsessively, concerned he would be accused of smelling, and each morning he scrubbed off the thick milky scent of sleep, the barnyard smell that wreathed him when he woke and impregnated the fabric of his pajamas. To the end of his life, he would never be seen without socks and shoes and would prefer shadow to light, faded days to sunny, for he was suspicious that sunlight might reveal him, in his hideousness, all too clearly." (TIOL 40)

When Jemubhai Patel returns to India as an ICS officer, he finds his wife Nimi very simple and his people alien. Having experienced seclusion in England, he cannot make a place for himself in his native land India. After his return, he finds himself armed with the cloak of a foreign degree that carries the colonizer's authoritarian seal. He becomes too English once he returns. The exercise of power "calmed him" (TIOL 61) for Jemubhai now "relished his power over the classes that had kept his family pinned under their heels for centuries" (TIOL 61). He mimics the British, eats toast for breakfast, and hunts animals with a gun. He is full of self-hate because of his Indian roots as well as hate for his immediate relations, his family, community, and even his wife. This behavioral tendency of the people of colonized countries to ape the rulers, as portrayed through the character of the judge, is the result of a sense of loss of self-esteem and dignity at the hands of the colonizers. Jemubhai thus restructures his psychic self and attempts to imbibe the same set of cultural values and norms that had caused him humiliation and insult. Jemubhai's attempts to mimic the British in their ways and customs can be explained by Bhabha's definition of the term 'mimicry'. Bhabha believes that "mimicry is the sign of a double articulation; a complex strategy of reform ... which 'appropriates' the Other as it visualises power" (Bhabha, 1994). Jemubhai wants to assume the power that is associated with the British imperialist government and he believes that imitating the British would help him achieve a power position that he or his family had never experienced before.

\section{Discussion}

Aparajita De defines home as an "antithesis to travel" (De, 2007). She adds that home signifies a difference from journey and displacement, but in The Inheritance of Loss the contours of home are redefined 
irrespective of physical journeys. Desai brings forth the fluidity of home and identity in the novel. The two characters of Biju and Father Booty are unhomed and then homed again during the course of the narrative, leaving them familiarised and defamiliarised at the same time. In the words of Said, they are "“filiated and affiliated"' (De, 2007) and at the end, they are left without affiliation to any particular culture. When Biju returns from the US, he becomes an unfamiliar figure without the glories associated with a newly arrived person from America. Biju is stripped of his clothes, belongings, and without his pride. The insurgents take away all his personal belongings from him and Biju is left without his hard-earned savings or the gifts that he had brought from America. When he reaches India from the land of liberty he cannot be identified as a wealthy America-returned person and all that remains of him now is only a bare piece of cloth that Biju uses to cover his body: "Darkness fell and he sat right in the middle of the path without his baggage, without his savings, worst of all, without his pride. Back from America with far less than he'd ever had." (TIOL 317)

Biju is forced to dress in rags that "must have been carefully picked from a pile at the bazaar" (TIOL 318). His shabby dress makes him hardly recognizable at all to the inhabitants of Cho-Oyu; he and the residents of the house have changed so much for each other. When Sai first sees Biju in the evening twilight, she fails to recognize him and thinks him to be a "bent-over woman dragging one leg onerously. She must be on her way elsewhere" (TIOL 324). Similarly, Father Booty's expulsion from Kalimpong is a case in point where his home of over four decades has to be abandoned within a couple of hours. Although he now returns to his original home in Europe, his country has now become unfamiliar to him. He is more familiar with the Himalayas of Kalimpong and the people there had become extended family to him. In the time of political uncertainty and insurgency, belonging, unbelonging and home become fluid and undergo a series of reconstructions. Aparajita De underlines how Father Booty's expulsion from Kalimpong implicitly lays bare the logic of how localities are constructed, a phenomenon she terms as "polygenesis" (De, 2007). De defines polygenesis as a "continual self-refashioning that characterises diasporic identity" (De, 2007). De's definition of 'polygenesis' explains how the process of refashioning of home and family affects almost all the characters in the novel. Characters like Father Booty and Biju are continuously subjected to an "evolution of the self under diverse contexts" (De, 2007), where they discover that their specificities of nationhood, culture, and identity are constantly challenged. Fortune seekers like Biju who move to another country on forged papers and characters like Father Booty who is from a developed country are ironically bound in a similar predicament, thereby making power positions relative. Both these characters' migration Biju moves to a developed nation from a developing one while Father Booty considers India as his home - suggest that not every character regards economic prosperity as the reason to migrate. This "fluid sense of home" (De, 2008) corrodes 'rootedness' and explodes the familiarity associated with 'home'. This 'othering' of the 'home country' and the immigrant is a dynamic process that is beyond the binaries of neat belongings and identifications. Belonging to and identifying with culture may not be always linear and simple. A character may find his or her 'home' in a diverse culture; a case in point is Father Booty.

McLeod suggests that "differences of gender, race, class, religion, and language (as well as generational differences) make diaspora spaces dynamic and shifting, open to repeated construction and reconstruction" (McLeod, 2007), and thus, identity is always in a state of flux. However, through the portrayal of Father Booty, Desai demonstrates that a character may consider a different culture familiar to him. The multiple, intersecting, and interrupting axes of differentiation and cohesion indicate the mutating subjectivity entailed in social relations and family. The novel blurs the distinction between the 'inside' and the 'outside'. The incorporation of the two worlds in the narrative demonstrates an awareness of the rebordering of cultural reality, which is necessary for a global and transnational imaginary that can no longer be fully encompassed within the old trope of national identity. Desai's novel upholds Rushdie's assertion that "'our identity is at once plural and partial'" (Liu, 2009). The characters are pitted against the "pull and push of transnational hybridising cultural force" (Liu, 2009). The novel emphasizes the effects of multiple and contradictory cultural inheritances on characters who themselves are the products of a transforming world. 


\section{Findings}

The Inheritance of Loss seems to appreciate the assimilationist notion of multicultural diversity brought in by individuals who maintain transnational affiliations. The two-world approach adopted by the novelist highlights how the dynamics between these separate locales are intertwined and interconnected and a determinant in family relationships. The emotional territory of the novel, with ties to more than one country, creates a transforming landscape of global interaction. The complication of 'homing' is all the more marked because Father Booty's coming to India and Biju's going to the US are for entirely different reasons. Biju's migration is because of economic compulsions, whereas Father Booty is a Jesuit priest engaged in social work in Kalimpong. Unlike Biju, Father Booty blends very well with the local people of Kalimpong and considers the place as his own. Although their contexts are vastly different, their cause of return is similar. Both characters are forced out of their adopted country. Like the judge, Biju is dislocated in a hostile foreign country. His father works very hard and saves money for Biju. It is for Biju that he ignores his health. The cook always advises letters to his son Biju and is concerned about his well-being:

"Make sure you are saving money. Don't lend to anyone and be careful who you talk to. There are many people out there who will say one thing and do another. Liars and cheats. Remember also to take rest. Make sure you eat enough. Health is wealth." (TIOL 18)

Similarly, when Biju comes to know about the political turmoil in Kalimpong, he is worried about his father. He arranges money as soon as possible and prepares himself to leave for India. He makes a phone call to his father to enquire about his wellbeing. He never lets his father know about his real condition because he knows his father would be disturbed by the news. Although Biju is discouraged by his friend who says:

"America is in the process of buying up the world. Go back, you'll find they own the business .... If you stay here, your son will earn a hundred thousand dollars for the same company he could be working for in India but making one thousand dollars." (TIOL 295)

Rushdie mentions in his Imaginary Homelands, "the writer who is out-of-country ... may experience this loss in an intensified form" (Rushdie, 1992). The fact of being 'elsewhere' generates discontinuity and this is reflected in the characters of the novel. Rushdie, although in a different context, had said many years before the publication of The Inheritance of Loss that Indian writers who live abroad, "are at one and the same time insiders and outsiders in this society" (Rushdie, 1992). Radhakrishnan corroborates Rushdie and comments, "belonging nowhere and everywhere at the same time, the diasporic subject may well attempt to proclaim a heterogeneous 'elsewhere' as its actual epistemological home" (Radhakrishnan, 2007). Desai explores the possibilities and problems engendered by the experience of being 'elsewhere'. Friedman maintains that "had this novel been published ten years ago, it may have been read as an examination of hybridity, an exploration of what Homi Bhabha saw as the outcome of global diaspora and migration" (Friedman, 2008). Friedman argues that Bhabha's use of words like 'disavowal', 'estrange', 'denied' suggests violence and that the "blending of cultures needs to be attended by the attack, war, and domination" (Friedman, 2008).

In The Inheritance of Loss, Biju does not pay heed to his advice and rushes to India. His worry for his father is evident from his decision to return. However, his return to India is accentuated by a series of mishaps. The closer he gets to home, the more unfamiliar he becomes to his people and surroundings. He is bereft of all the material possessions that would have identified him as the America-returned son of Panna Lal, the cook. The cook had expected that his son would return from the US as a wealthy person. The cook had presented his son Biju as someone who's making it big in the US and earning lots of money there. But 
when Biju returns dressed in rags and without costly gifts or belongings, he is hardly recognizable. The theft of his earnings by the insurgents serves to sever his last tie to New York, effectively making it as though he had never visited the US. For the cook, Biju is unfamiliar because the latter doesn't quite fit into the expected notion of someone who's just returned from the US. Subjectivities become configured as an effect of history and the town of Kalimpong becomes the site of return for all characters except Father Booty. It is the place that unites the characters where Sai, the judge, Biju, Lola, and Noni find accommodation amidst the different strata of Kalimpong society. Desai's novel has a closed ending where the principal migrant character Biju returns permanently to India without carrying any streak of American culture or material possessions from the US. The novel ends with the affirmation of love and union of father and son where neither of them has any expectation towards the other. Desai emphasizes unadulterated love that is devoid of any material expectations or possessions.

\section{Conclusion}

Desai creates characters who are positioned within the turns of subcontinental history and ultimately ends the novel with a positive note. The novel demonstrates the effect of geo-cultural complexities arising out of sub-continental history on characters and the subsequent affirmation of family relations. The culturally dynamic melting pot of the Kalimpong society becomes the site of reunion between Biju and the cook. Although the narrative shuttles back and forth between the two contrasting worlds of Manhattan and Kalimpong, one marked by "trains passing by in a devilish screaming, their wheels sparked firework showers" (TIOL 147) and the other being continuously thrust into a vortex of geopolitical disturbance of Gorkhaland insurgency, Desai emphasizes future positive possibilities in the lives of her characters. The tormented past of the characters and the uncertain present in the context of illegal immigration to the US and the Gorkhaland agitation of the 80s brings out the historical and geographical problems and their effects on family relationships. However, by showing the reunion of Biju with his father, Desai affirms the strength of filial relations. Biju's meeting with his father amidst the turbulent Gorkhaland insurgency in the backdrop reinforces the bond of love that is there between father and son. The ending of the novel heralds a positive beginning of the father-son relationship where neither of them has any expectation towards the other. Unadulterated love against the backdrop of the golden Kanchenjunga seems to the ultimate message coming from the novelist. Desai hints towards positive possibilities in the lives of her characters. Sai's mistaking Biju as Gyan and her thinking to herself that she will forgive him point towards a possibility of a reunion between Sai and Gyan. Even the possibility of Mutt's return is hinted at the last page of the novel when Sai thinks the figure to be someone who has come to return Jemubhai's only companion. The novelist endorses the bond of love without expectations that ultimately emerge triumphant during and after the process of migration by the characters. This research provides a chance to understand the impact of Post-Partitioned (1947) ideologies behind the theme selection in the writings of diasporic Anglophone writers.

\section{References}

Desai, K. (2006). The Inheritance of Loss. New Delhi: Penguin. (All the page references are cited from this edition only, "TIOL" is used for "The Inheritance of Loss" within the paper.)

Agarwal, B. (2009). “Kiran Desai's The Inheritance of Loss: A Parable on the Predicament of Third World Immigrants.” In Critical Responses to Kiran Desai, edited by Sunita Sinha, and Bryan Reynolds, New Delhi: Atlantic Publishers. 210-219.

Ashcroft, B., Griffiths, G., and Tiffin, H. (2009). Post-Colonial Studies The Key Concepts. London and New York: Routledge. 
Bauman, Z. (1996). "From Pilgrim to Tourist" or a Short History of Identity.” In Questions of Cultural Identity, edited by Stuart Hall and Paul du Gay, London: Sage. 18-36.

Bhabha, H. K. (1994). The Location of Culture. London and New York: Routledge.

Castillo, D. (1995). “Interview with John Rechy.” Diacritics 25(1):112-125.

Chuh, K. (1996). “Transnationalism and its Pasts.” Public Culture 9(1):93-112.

De, A. (2007). "What's In a Name? Tropes of Belonging and Identity in The Namesake." South Asian Review 28(2):182-200.

Friedman, N. (2008). “From Hybrids to Tourists: Children of Immigrants in Jhumpa Lahiri’s The Namesake." Critique: Studies in Contemporary Fiction 50(1):1-10.

Liu, Y. (2009). “Transnational Hybridity and Re-(b)ordering Cultural Reality in Kiran Desai's The Inheritance of Loss." Tamkang Review 40(1):97-117.

Mishra, V. (1996). “The Diasporic Imaginary: Theorising the Indian Diaspora.” Textual Practice 10(3): 421-452.

Radhakrishnan, R. (2007). Between Identity and Location, The Cultural Politics of Theory. Hyderabad: Orient Longman.

Rehman, G. (2009). “Kiran Desai’s The Inheritance of Loss: A Study in Themes of Rootlessness, Alienation and Death.” In Critical Responses to Kiran Desai, edited by Sunita Sinha, and Bryan Reynolds, New Delhi: Atlantic Publishers. 118-144.

Rushdie, S. (1992). Imaginary Homelands Essays and Criticism 1981-1991. London: Granta Books.

Scanlan, M. (2010). "Migrating from Terror: The Postcolonial Novel after September 11.” Journal of Postcolonial Writing 46(3-4): 266-278.

Sen, S. (2009). “The Inheritance of Loss: Individuals in Search of the Lost Identity.” In Critical Responses to Kiran Desai, edited by Sunita Sinha, and Bryan Reynolds, New Delhi: Atlantic Publishers. 99-109.

Sinha, S. and Reynolds, B. (2010). Critical Responses to Kiran Desai. New Delhi: Atlantic Publishers.

Smith, A. (2004). "Migrancy, hybridity, and postcolonial literary studies." In The Cambridge Companion to Postcolonial Literary Studies, edited by Neil Lazarus, Cambridge: 
Cambridge University Press. 241-261.

Spielman, D. (2010). "Solid Knowledge and Contradictions in Kiran Desai's The Inheritance of Loss." Critique 51(1):74-89.

Toloyan, K. (1996). "Rethinking Diaspora(s): Stateless Power in the Transnational Moment." Diaspora 5(1): 2-36. 